\title{
Review of Regional Finance of Government of Regency and City in West Sumatera Province
}

\author{
Halkadri Fitra \\ \{halkadri.feunp@gmail.com\} \\ Faculty of Economic Universitas Negeri Padang, Padang, Indonesia
}

\begin{abstract}
This study aims to see the regional financial independence in 12 regencies and 7 cities in West Sumatera Province in the period 2012 to 2016. The data used are secondary data that is the realization of local revenue, total regional revenues, revenue transfer from the central government, others legitimate regional revenue as well as regional loans obtained from the Directorate General of Fiscal Balance at the Ministry of Finance of the Republic of Indonesia. This research is categorized into quantitative descriptive research so that it can give an explanation about the condition of regional financial independence. The results showed that the average ratio of financial independence of regency and municipal governments in West Sumatera Province is in very low category with value of $8.43 \%$ and has an instructive relationship pattern. The ratio of municipal autonomy of city government with the value of $11.29 \%$ higher than the district government which has a value of $6.77 \%$. Nevertheless, from 2012 to 2016, district and city governments have attempted to raise the local financial independence ratio from $5.55 \%$ to $7.70 \%$ for district governments and from $9.67 \%$ to $12.67 \%$ for municipalities. For the district government, which has the highest ratio of regional financial independence in 2012 is Dharmasraya District and in 2013 to 2016 is Tanah Datar regency. As for the city government, starting from 2012 until 2016, the highest ratio of financial independence is obtained by the city of Padang. To improve the regional financial independence ratio, district and city governments are expected to optimize the components of local revenue, build better and more innovative local financial management systems and maintain sustainable regional investment conditions.
\end{abstract}

Keywords: City; Independence Ratio; Regency; Regional Finance

\section{Introduction}

Regency and city regional governments in Indonesia since the commencement of the era of regional autonomy, continue to strive to increase regional original revenue by exploring all the potential of the region that is owned to accelerate the welfare of the community. Based on Law Number 23 of 2014 concerning regional governance (Presiden Indonesia dan DPRRI, 2014), regional autonomy is defined as the rights, authorities and obligations of autonomous regions to regulate and manage their own affairs and the interests of the local community in the system of the Republic of Indonesia. According to (Halim, 2001, p. 167) the main characteristics of an area capable of carrying out autonomy are:

- Regional financial capacity, meaning that regions must have the authority and ability to explore financial resources, manage and use their own funds that are sufficient to finance the administration of their governance. 
- Dependence on central assistance must be as minimal as possible so that local revenue (PAD) can be the largest part of financial resources. Thus, the role of local government becomes greater.

Along with the spirit of regional autonomy, the regency and city governments in West Sumatra Province also do not want to be left behind with other regions in Indonesia. This is indicated by the continued increase in revenue from regency and city government revenue from year to year. As an illustration, the realization of local revenue for the regencies and cities in West Sumatra can be seen in the following table:

Table 1. Realization of Regional Original Revenue of Regency and City Governments in West Sumatra Province $2012-2016$

\begin{tabular}{|c|c|c|c|c|c|c|}
\hline $\mathrm{N}$ & $\begin{array}{c}\text { Regency/C } \\
\text { ity }\end{array}$ & 2012(IDR) & 2013(IDR) & 2014(IDR) & 2015(IDR) & 2016(IDR) \\
\hline 1 & $\begin{array}{l}\text { Agam } \\
\begin{array}{l}\text { Rege } \\
\text { ncy }\end{array}\end{array}$ & $\begin{array}{c}41.572 .966 .2 \\
40\end{array}$ & $\begin{array}{c}49.954 .056 .8 \\
82\end{array}$ & $\begin{array}{c}79.418 .015 .1 \\
01\end{array}$ & $\begin{array}{c}90.197 .210 .2 \\
98\end{array}$ & $\begin{array}{c}102.597 .441 \\
502\end{array}$ \\
\hline 2 & $\begin{array}{c}\text { Dharmasra } \\
\text { ya } \\
\text { Rege } \\
\text { ncy }\end{array}$ & $\begin{array}{c}39.200 .742 .6 \\
10\end{array}$ & $\begin{array}{c}32.902 .332 .2 \\
60\end{array}$ & $\begin{array}{c}52.811 .257 .4 \\
15\end{array}$ & $\begin{array}{c}56.694 .339 .2 \\
06\end{array}$ & $\begin{array}{c}56.453 .463 .1 \\
78\end{array}$ \\
\hline 3 & $\begin{array}{l}\text { Kepulauan } \\
\text { Mentawai } \\
\text { Regency }\end{array}$ & $\begin{array}{c}34.639 .147 .8 \\
38\end{array}$ & $\begin{array}{c}31.302 .498 .6 \\
04\end{array}$ & $\begin{array}{c}36.444 .071 .1 \\
05\end{array}$ & $\begin{array}{c}42.784 .854 .4 \\
85\end{array}$ & $\begin{array}{c}41.948 .183 .1 \\
05\end{array}$ \\
\hline 4 & $\begin{array}{l}\text { Lima } \\
\qquad \begin{array}{l}\text { Puluh } \\
\text { Kota } \\
\text { Rege } \\
\text { ncy }\end{array}\end{array}$ & $\begin{array}{c}24.936 .552 .4 \\
95\end{array}$ & $\begin{array}{c}33.095 .121 .0 \\
16\end{array}$ & $\begin{array}{c}52.829 .354 .3 \\
64\end{array}$ & $\begin{array}{c}62.932 .793 .3 \\
03\end{array}$ & $\begin{array}{c}68.060 .267 .4 \\
76\end{array}$ \\
\hline 5 & $\begin{array}{l}\text { Padang } \\
\text { Paria } \\
\text { man } \\
\text { Rege } \\
\text { ncy }\end{array}$ & $\begin{array}{c}31.287 .086 .2 \\
22\end{array}$ & $\begin{array}{c}42.619 .951 .1 \\
69\end{array}$ & $\begin{array}{c}72.878 .860 .0 \\
51\end{array}$ & $\begin{array}{c}72.995 .950 .8 \\
34\end{array}$ & $\begin{array}{c}72.859 .394 .0 \\
01\end{array}$ \\
\hline 6 & $\begin{array}{c}\text { Pasaman } \\
\text { Rege } \\
\text { ncy }\end{array}$ & $\begin{array}{c}33.037 .265 .5 \\
33\end{array}$ & $\begin{array}{c}46.023 .665 .8 \\
62\end{array}$ & $\begin{array}{c}72.878 .860 .0 \\
51\end{array}$ & $\begin{array}{c}79.684 .485 .7 \\
86\end{array}$ & $\begin{array}{c}88.862 .264 .2 \\
00\end{array}$ \\
\hline 7 & $\begin{array}{l}\text { Pasaman } \\
\text { Barat } \\
\text { Rege } \\
\text { ncy }\end{array}$ & $\begin{array}{c}32.493 .954 .0 \\
54\end{array}$ & $\begin{array}{c}37.826 .530 .9 \\
33\end{array}$ & $\begin{array}{c}69.925 .195 .4 \\
82\end{array}$ & $\begin{array}{c}69.128 .838 .7 \\
35\end{array}$ & $\begin{array}{c}91.174 .717 .1 \\
14\end{array}$ \\
\hline
\end{tabular}




\begin{tabular}{|c|c|c|c|c|c|c|}
\hline $\mathrm{N}$ & $\begin{array}{c}\text { Regency/C } \\
\text { ity }\end{array}$ & 2012(IDR) & 2013(IDR) & 2014(IDR) & 2015(IDR) & 2016(IDR) \\
\hline 8 & $\begin{array}{l}\text { Pesisir } \\
\quad \text { Selata } \\
\text { n } \\
\text { Rege } \\
\text { ncy }\end{array}$ & $\begin{array}{c}40.254 .884 .2 \\
12\end{array}$ & $\begin{array}{c}47.703 .256 .3 \\
02\end{array}$ & $\begin{array}{c}86.699 .821 .7 \\
43\end{array}$ & $\begin{array}{c}107.992 .020 . \\
496\end{array}$ & $\begin{array}{c}108.915 .294 \\
628\end{array}$ \\
\hline 9 & $\begin{array}{c}\text { Sijunjung } \\
\text { Rege } \\
\text { ncy }\end{array}$ & $\begin{array}{c}32.813 .105 .4 \\
94\end{array}$ & $\begin{array}{c}38.098 .006 .8 \\
12\end{array}$ & $\begin{array}{c}54.261 .420 .0 \\
00\end{array}$ & $\begin{array}{c}65.008 .435 .9 \\
21\end{array}$ & $\begin{array}{c}76.833 .967 .6 \\
29\end{array}$ \\
\hline 1 & $\begin{array}{l}\text { Solok } \\
\quad \begin{array}{l}\text { Rege } \\
\text { ncy }\end{array}\end{array}$ & $\begin{array}{c}26.479 .471 .5 \\
22\end{array}$ & $\begin{array}{c}31.491 .005 .2 \\
12\end{array}$ & $\begin{array}{c}51.502 .14855 \\
0\end{array}$ & $\begin{array}{c}55.610 .732 .9 \\
18\end{array}$ & $\begin{array}{c}58.803 .477 .2 \\
33\end{array}$ \\
\hline 1 & $\begin{array}{l}\text { Solok } \\
\quad \begin{array}{l}\text { Selata } \\
\text { n } \\
\text { Rege } \\
\text { ncy }\end{array}\end{array}$ & $\begin{array}{c}22.054 .660 .9 \\
88\end{array}$ & $\begin{array}{c}22.225 .149 .6 \\
73\end{array}$ & $\begin{array}{c}32.342 .605 .6 \\
37\end{array}$ & $\begin{array}{c}41.207 .396 .9 \\
26\end{array}$ & $\begin{array}{c}51.138 .125 .8 \\
57\end{array}$ \\
\hline 1 & $\begin{array}{l}\text { Tanah } \\
\text { Datar } \\
\text { Rege } \\
\text { ncy }\end{array}$ & $\begin{array}{c}53.691 .047 .5 \\
86\end{array}$ & $\begin{array}{c}63.835 .093 .7 \\
87\end{array}$ & $\begin{array}{c}99.694 .236 .7 \\
63\end{array}$ & $\begin{array}{c}112.072 .726 \\
548\end{array}$ & $\begin{array}{c}118.971 .143 . \\
694\end{array}$ \\
\hline 1 & $\begin{array}{l}\text { Bukit } \\
\text { Tinggi } \\
\text { City } \\
\text { KotaPadan } \\
\text { g }\end{array}$ & $\begin{array}{c}45.076 .555 .8 \\
41\end{array}$ & $\begin{array}{c}55.203 .591 .6 \\
05\end{array}$ & $\begin{array}{c}61.613 .681 .0 \\
43\end{array}$ & $\begin{array}{c}66.027 .359 .7 \\
16\end{array}$ & $\begin{array}{c}71.303 .781 .7 \\
36\end{array}$ \\
\hline 1 & $\begin{array}{l}\text { City } \\
\quad \text { Padan } \\
\text { g }\end{array}$ & $\begin{array}{c}189.450 .840 \\
075\end{array}$ & $\begin{array}{c}238.871 .896 . \\
576\end{array}$ & $\begin{array}{c}315.678 .797 \\
930\end{array}$ & $\begin{array}{c}370.413 .732 . \\
165\end{array}$ & $\begin{array}{c}391.925 .662 . \\
647\end{array}$ \\
\hline 1 & $\begin{array}{c}\text { Panjang } \\
\text { City } \\
\text { Paria } \\
\text { man }\end{array}$ & $\begin{array}{c}32.420 .607 .3 \\
00\end{array}$ & $\begin{array}{c}41.513 .490 .0 \\
00\end{array}$ & $\begin{array}{c}51.601 .386 .4 \\
98\end{array}$ & $\begin{array}{c}67.035 .654 .3 \\
11\end{array}$ & $\begin{array}{c}70.357 .124 .0 \\
66\end{array}$ \\
\hline 1 & $\begin{array}{l}\text { City } \\
\begin{array}{l}\text { Payak } \\
\text { umbu } \\
\text { ah }\end{array}\end{array}$ & $\begin{array}{c}17.578 .732 .4 \\
32\end{array}$ & $\begin{array}{c}20.639 .400 .0 \\
00\end{array}$ & $\begin{array}{c}26.677 .826 .1 \\
64\end{array}$ & $\begin{array}{c}29.897 .289 .1 \\
37\end{array}$ & $\begin{array}{c}29.680 .784 .1 \\
58\end{array}$ \\
\hline
\end{tabular}

\begin{tabular}{lllllll}
1 & City & 50.708 .914 .1 & 54.177 .950 .8 & 65.900 .626 .2 & 100.646 .557$. & 87.445 .115 .9 \\
\hline
\end{tabular}




\begin{tabular}{|c|c|c|c|c|c|c|}
\hline $\mathrm{N}$ & $\begin{array}{c}\text { Regency/C } \\
\text { ity }\end{array}$ & 2012(IDR) & 2013(IDR) & 2014(IDR) & 2015(IDR) & 2016(IDR) \\
\hline & $\begin{array}{l}\text { Sawa } \\
\text { hlunt } \\
\text { o }\end{array}$ & 24 & 40 & 16 & 921 & 02 \\
\hline 1 & City & $\begin{array}{c}34.887 .767 .7 \\
57\end{array}$ & $\begin{array}{c}37.104 .573 .7 \\
91\end{array}$ & $\begin{array}{c}37.104 .573 .7 \\
91\end{array}$ & $\begin{array}{c}52.268 .500 .5 \\
28\end{array}$ & $\begin{array}{c}53.388 .553 .9 \\
83\end{array}$ \\
\hline 1 & Solok City & $\begin{array}{c}23.302 .507 .6 \\
96\end{array}$ & $\begin{array}{c}24.140 .144 .8 \\
14\end{array}$ & $\begin{array}{c}29.522 .144 .8 \\
14\end{array}$ & $\begin{array}{c}36.630 .731 .4 \\
03\end{array}$ & $\begin{array}{c}42.117 .207 .7 \\
38\end{array}$ \\
\hline
\end{tabular}

Source: www.djpk.kemenkeu.go.id 2018 (data processed)

Based on the above table, we can see that in general the realization of revenue from local and district and municipal government revenues in West Sumatra continues to increase year by year. This is driven by the regional desire to implement regional autonomy well and continuously. The implementation of regional autonomy is essentially an effort to achieve community prosperity so that it must be carried out equitably and continuously. (Bastian, 2011) reveals that the purpose of regional autonomy is basically directed to spur the equitable distribution of development and its results, improve people's welfare, promote initiatives and community participation, and increase the utilization of regional potential in a real, optimal, integrated and dynamic manner. And responsible so as to strengthen the unity and integrity of the nation, reduce the burden on the central government and intervene in the region and provide opportunities for coordination at the local or regional level.

To optimize regional autonomy, the district and city governments must be able to utilize the resources they possess through creative and innovative policies. Especially in the financial sector, the regional government should be able to maximize revenue, then use the revenue for the right target.

According to (Halim and Theresia, 2011, p. 111) regional financial independence (fiscal autonomy) shows the ability of local governments to self-finance government activities, development and services to communities who have paid taxes and retributions as a source of income needed by the region. Regional financial independence is indicated by the size of the region's original income compared to regional income from other sources, such as central government assistance or loans so that even though the quantity of local revenue continues to increase every year, it has not become a reference that the regions have increased independently, it is necessary to look at other aspects of revenue from outside the region's original income.

The regional government financial reports that are reported to the central government annually and also carried out by the Republic of Indonesia Financial Examination Agency (BPK-RI) can provide information to see the realization of local revenues and realization of revenues other than local revenue so that it can help to see regional financial independence. Based on this, the researcher makes the formulation of the problem in this study how is the financial independence of the regency and city in West Sumatra Province?

Based on the formulation of the problem, the purpose of this study was to look at the financial independence of the regencies and cities in West Sumatra Province. 


\section{Literature Review}

Government Regulation Number 71 of 2010 concerning Government Accounting Standards there are seven components of local government financial statements namely Budget Realization Report, Over Budget Balance Change Report, Balance Sheet, Equity Change Report, Operational Report, Cash Flow Statement and Notes to Financial Statements. The main purpose of financial statements is to provide information that is useful to users in making and evaluating decisions (Fahmi, 2011).

Information on financial statements submitted by local governments must be interpreted by users of the report to provide an assessment of the achievements. In accordance with the Signal Theory (Signaling Theory), the government as the party given the mandate by the people, wishes to show a signal to the public. The government will give a signal to the public by providing quality financial reports, improving internal control systems, more complete disclosures. In addition the regional government can also package achievement information and financial performance more fully to show that the local government has carried out the mandate given by the people (Puspita and Martani, 2010).

In Law Number 23 of 2014 (Presiden Indonesia dan DPRRI, 2014), regional financial independence means that the government can carry out financing and financial accountability itself, implementing itself in the framework of decentralization. (Tangkilisan, 2007, pp. 8292) suggests that there are factors that influence regional financial independence, including:

- Regional economic potential, an indicator that is widely used as a benchmark for regional economic potential is the Gross Regional Domestic Product.

- The ability of the Regional Revenue Service, meaning that regional financial independence can be increased in a planned manner through the ability or performance of innovative institutions or institutions and the utilization of Regional Revenue Service institutions to increase regional revenues.

Regional financial independence can be seen from the amount of Regional Original Revenue compared to receipt of transfers from the center. Regional Original Income is the main element in measuring regional financial independence. According to (Halim, 2007, p. 96) "Regional Original Revenue is all regional revenues that come from local economic sources". Regional Original Revenue is sourced from the results of local taxes, the results of regional retribution, the results of the management of separated regional assets, and other legitimate local revenues. In connection with the above, each region is expected to be able to increase Regional Original Revenue to reach an independent region. According to (Mahmudi, 2007, p. 128) Regional Financial Independence Ratios can be formulated as follows:

$$
R K K D=\frac{P A D}{T P S+T P r+P j m}
$$

Information:

$\begin{array}{ll}\text { RKKD } & \text { : Regional Financial Independence Ratio } \\ \text { PAD } & \text { : Regional Original Income } \\ \text { TPs } & \text { : Transfer of Central Government } \\ \text { TPr } & \text { : Transfer of Provincial Government } \\ \text { Pjm } & \text { : Loan }\end{array}$

The ratio of regional financial independence will show the pattern of relations between the central government and the regions. According to (Halim, 2001, p. 2012) patterns of 
relationships that occur from the results of the calculation of regional financial independence ratios are as follows:

Table 2. Regional Financial Independence Interval Scale

\begin{tabular}{ccc}
\hline $\begin{array}{c}\text { Percentag } \\
\mathrm{e} \\
\text { scale }\end{array}$ & Information & $\begin{array}{c}\text { Relationship } \\
\text { Pattern }\end{array}$ \\
\hline $0-25$ & Very Low & Instructive \\
\hline $25-50$ & Low & Consultative \\
\hline $50-75$ & Medium & Participatory \\
\hline $75-100$ & High & Delegated \\
\hline \multicolumn{3}{c}{ Source: Halim (2012) }
\end{tabular}

The pattern of relations between the central government and regional governments in the implementation of regional autonomy is primarily the implementation of Law Number 33 of 2004 (INDONESIA, 2004) concerning Financial Balance between the Central Government and Regional Governments according to (Halim, 2001, p. 168), among others.

- An instructive relationship pattern, namely the role of the central government is more dominant than the independence of local governments (regions are not able to carry out regional autonomy financially).

- The pattern of consultative relations, namely the intervention of the central government has begun to diminish and more in the provision of consultation because the regions are considered to be slightly more able to implement regional autonomy.

- The pattern of participatory relations, namely the pattern in which the role of the central government is diminishing given the level of independence of the autonomous regions concerned is close to being able to carry out autonomy affairs. The role of consultation is shifting to the role of central government participation.

- The pattern of delegated relations, namely the intervention of the central government no longer exists because the region has been truly capable and independent in carrying out regional autonomy affairs. The central government is ready and with full confidence delegates financial autonomy to the regional government.

Some studies on regional financial independence and regional financial performance include (Ramadhani, 2016) who conducted research entitled Analysis of Independence and Regional Financial Effectiveness in Tarakan City in 2010-2015 concluded that the Tarakan City Government had regional financial independence with a ratio of between $75 \%-100 \%$ so that it will have a pattern of delegated relations. In addition (Haryani, 2016) also conducted a study entitled Analysis of the Independence and Financial Effectiveness of Bireuen District concluded that Bireuen District had a regional financial independence ratio with an average value of $6.32 \%$ which could be categorized as very low (below 25\%) with an instructive relationship pattern.

Similarly, (Rahmayati, 2016) has conducted research with the title Analysis of the Financial Performance of the Regional Government of Sukoharjo Regency in Fiscal Year 2011-2013 resulting in research showing that the financial performance of the Sukoharjo Regency Government is still not optimal. Although the management of Regional Original Revenue is effective and efficient, the level of regional independence is still very low. (Risyanto, 2015) also carried out research with the title Analysis of Regional Financial Capabilities and Regional Financial Independence and Their Influence on the Economic 
Growth of Garut Regency in the 2004-2013 budget year which concluded that the regional independence ratio indicated by the average ratio was $6,39 \%$ are still between $0 \%-25 \%$ classified as having an instructive relationship pattern which means the ability of the Garut Regency Government to meet the funding needs for the administration of the tasks of Government, Development and Community Social Services is still relatively low even though from year to year it continues to increase. (Fitra, 2014) specifically conducted research on regional financial independence ratios in the autonomous era of the parent and new regency governments conducted in the Pasaman Regency and West Pasaman Regency Governments to obtain the conclusion of the regional financial independence ratio of West Pasaman Regency in 2008 - 2013 is $5.38 \%$ higher compared to Pasaman Regency which is $4.88 \%$. To better direct research towards the objectives to be achieved, the research framework is made as follows:

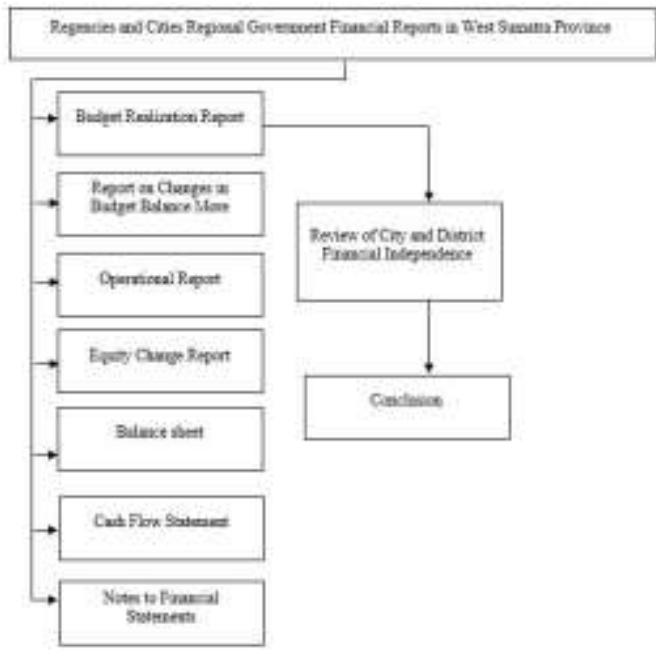

Fig. 1. Research Framework

\section{Methodology}

The research approach used by this research is a descriptive research approach that describes the condition of the financial independence of districts and cities in West Sumatra Province. The object of the research is a report on the realization of the government budget of districts and cities in West Sumatra Province, amounting to 19 consisting of 12 regencies and 7 cities namely Agam Regency, Dharmasraya Regency, Mentawai Islands Regency, Limapuluh Kota Regency, Padang Pariaman Regency, Pasaman Regency, West Pasaman Regency, South Pesisir Regency, Sijunjung District, Solok Regency, South Solok Regency, Tanah Datar Regency, Bukit Tinggi City, Padang City, Padang Panjang City, Pariaman City, Payakumbuh City, Sawahlunto City and Solok City. According to the method of obtaining it, this study used secondary data types in 2012 to 2016. Secondary data in this study were reports on the realization of district and city government budgets in West Sumatra Province. Data collection techniques used are documentation methods by recording and tracing data on district and city budget realization reports that are officially published through the website of the Directorate General of Financial Balance of the Ministry of Finance of the Republic of Indonesia. 


\section{Results And Discussion}

The average financial independence of the regencies and cities in West Sumatra Province in 2012 to 2016 is as follows:

Table 3. Ratio of District and City Financial Independence in West Sumatera Province 2012 2016

\begin{tabular}{|c|c|c|c|c|c|c|c|c|c|}
\hline \multirow[t]{2}{*}{$\mathrm{N}$} & \multirow[t]{2}{*}{$\begin{array}{c}\text { Regency/Ci } \\
\text { ty }\end{array}$} & \multicolumn{5}{|c|}{$\begin{array}{l}\text { Ragional Financial Independence } \\
\text { Ratio (\%) }\end{array}$} & \multirow[t]{2}{*}{$\begin{array}{r}\text { Avera } \\
\text { ge }\end{array}$} & \multirow[t]{2}{*}{$\begin{array}{r}\text { Criter } \\
\text { ia }\end{array}$} & \multirow[t]{2}{*}{$\begin{array}{l}\text { elationship } \\
\text { Pattera }\end{array}$} \\
\hline & & $\begin{array}{r}201 \\
2\end{array}$ & $\begin{array}{r}201 \\
3\end{array}$ & $\begin{array}{r}201 \\
4\end{array}$ & $\begin{array}{r}201 \\
5\end{array}$ & $\begin{array}{r}201 \\
6\end{array}$ & & & \\
\hline 1 & $\begin{array}{l}\text { Agam } \\
\text { Regency }\end{array}$ & 4.96 & 5.25 & 7.55 & 7.61 & 8.23 & 6.72 & $\begin{array}{l}\text { Verry } \\
\text { Low }\end{array}$ & $\begin{array}{c}\text { Instructi } \\
\text { ve }\end{array}$ \\
\hline 2 & $\begin{array}{c}\text { Dharmasra } \\
\text { ya } \\
\text { Regenc } \\
\text { y }\end{array}$ & 8.18 & 5.85 & 8.32 & 7.68 & 6.90 & 7.39 & $\begin{array}{l}\text { Verry } \\
\text { Low }\end{array}$ & $\begin{array}{c}\text { Instructi } \\
\text { ve }\end{array}$ \\
\hline 3 & $\begin{array}{l}\text { Kepulauan } \\
\text { Mentawai } \\
\text { Regency }\end{array}$ & 7.45 & 5.26 & 5.53 & 5.44 & 4.83 & 5.70 & $\begin{array}{l}\text { Verry } \\
\text { Low }\end{array}$ & $\begin{array}{c}\text { Instructi } \\
\text { ve }\end{array}$ \\
\hline 4 & $\begin{array}{l}\text { Lima Puluh } \\
\text { Kota } \\
\text { Regenc } \\
\text { y }\end{array}$ & 3.39 & 3.87 & 5.55 & 5.86 & 6.13 & 4.96 & $\begin{array}{l}\text { Verry } \\
\text { Low }\end{array}$ & $\begin{array}{c}\text { Instructi } \\
\text { ve }\end{array}$ \\
\hline 5 & $\begin{array}{l}\text { Padang } \\
\text { Pariam } \\
\text { an } \\
\text { Regenc } \\
\text { y }\end{array}$ & 4.13 & 4.66 & 9.84 & 6.51 & 5.69 & 6.17 & $\begin{array}{l}\text { Verry } \\
\text { Low }\end{array}$ & $\begin{array}{c}\text { Instructi } \\
\text { ve }\end{array}$ \\
\hline 6 & $\begin{array}{l}\text { Pasaman } \\
\text { Regenc } \\
\mathrm{y}\end{array}$ & 5.54 & 7.18 & 9.84 & 9.84 & $\begin{array}{r}10.0 \\
7\end{array}$ & 8.49 & $\begin{array}{l}\text { Verry } \\
\text { Low }\end{array}$ & $\begin{array}{c}\text { Instructi } \\
\text { ve }\end{array}$ \\
\hline 7 & $\begin{array}{r}\text { Pasaman } \\
\text { Barat }\end{array}$ & 5.44 & 3.33 & 8.62 & 7.72 & 9.32 & 7.29 & Verry & Instructi \\
\hline
\end{tabular}




\begin{tabular}{|c|c|c|c|c|c|c|c|c|c|}
\hline \multirow[t]{3}{*}{$\mathrm{N}$} & \multirow[t]{2}{*}{$\begin{array}{c}\text { Regency/Ci } \\
\text { ty }\end{array}$} & \multicolumn{5}{|c|}{$\begin{array}{l}\text { Ragional Financial Independence } \\
\text { Ratio (\%) }\end{array}$} & \multirow[t]{2}{*}{$\begin{array}{r}\text { Avera } \\
\text { ge }\end{array}$} & \multirow[t]{2}{*}{$\begin{array}{r}\text { Criter } \\
\text { ia }\end{array}$} & \multirow[t]{2}{*}{$\begin{array}{l}\text { elationship } \\
\text { Pattera }\end{array}$} \\
\hline & & $\begin{array}{r}201 \\
2\end{array}$ & $\begin{array}{r}201 \\
3\end{array}$ & $\begin{array}{r}201 \\
4\end{array}$ & $\begin{array}{r}201 \\
5\end{array}$ & $\begin{array}{r}201 \\
6\end{array}$ & & & \\
\hline & $\begin{array}{l}\text { Regenc } \\
\mathrm{y}\end{array}$ & & & & & & & Low & ve \\
\hline 8 & $\begin{array}{l}\text { Pesisir } \\
\text { Selatan } \\
\text { Regenc } \\
\text { y }\end{array}$ & 4.84 & 4.88 & 7.97 & 8.51 & 8.07 & 6.86 & $\begin{array}{l}\text { Verry } \\
\text { Low }\end{array}$ & $\begin{array}{c}\text { Instructi } \\
\text { ve }\end{array}$ \\
\hline 9 & $\begin{array}{l}\text { Sijunjung } \\
\text { Regenc } \\
\mathrm{y}\end{array}$ & 6.28 & 6.13 & 7.82 & 8.52 & 9.51 & 7.65 & $\begin{array}{l}\text { Verry } \\
\text { Low }\end{array}$ & $\begin{array}{c}\text { Instructi } \\
\text { ve }\end{array}$ \\
\hline 1 & $\begin{array}{l}\text { Solok } \\
\text { Regenc } \\
\mathrm{y}\end{array}$ & 3.78 & 3.81 & 5.49 & 5.32 & 5.50 & 4.78 & $\begin{array}{l}\text { Verry } \\
\text { Low }\end{array}$ & $\begin{array}{c}\text { Instructi } \\
\text { ve }\end{array}$ \\
\hline 1 & $\begin{array}{l}\text { Solok } \\
\text { Selatan } \\
\text { Regenc } \\
\text { y }\end{array}$ & 5.02 & 4.51 & 5.41 & 5.90 & 7.05 & 5.58 & $\begin{array}{l}\text { Verry } \\
\text { Low }\end{array}$ & $\begin{array}{c}\text { Instructi } \\
\text { ve }\end{array}$ \\
\hline 1 & $\begin{array}{l}\text { Tanah } \\
\text { Datar } \\
\text { Regenc } \\
y\end{array}$ & 7.60 & 7.70 & $\begin{array}{r}11.0 \\
2\end{array}$ & $\begin{array}{r}10.7 \\
8\end{array}$ & $\begin{array}{r}11.1 \\
2\end{array}$ & 9.64 & $\begin{array}{l}\text { Verry } \\
\text { Low }\end{array}$ & $\begin{array}{c}\text { Instructi } \\
\text { ve }\end{array}$ \\
\hline & $\begin{array}{l}\text { age } \\
\text { Regency) }\end{array}$ & 5.55 & 5.37 & 7.75 & 7.47 & 7.70 & 6.77 & $\begin{array}{l}\text { Verry } \\
\text { Low }\end{array}$ & $\begin{array}{c}\text { Instructi } \\
\text { ve }\end{array}$ \\
\hline 1 & $\begin{array}{l}\text { Bukit } \\
\text { Tinggi City } \\
\text { KotaPadan } \\
\text { g }\end{array}$ & 10.83 & 11.69 & 11.54 & 12.52 & 12.38 & 11.79 & $\begin{array}{l}\text { Verry } \\
\text { Low }\end{array}$ & $\begin{array}{c}\text { Instructi } \\
\text { ve }\end{array}$ \\
\hline 1 & $\begin{array}{l}\text { City } \\
\text { Padang }\end{array}$ & $\begin{array}{r}14.7 \\
3\end{array}$ & $\begin{array}{r}16.1 \\
9\end{array}$ & $\begin{array}{r}19.7 \\
6\end{array}$ & $\begin{array}{r}23.4 \\
9\end{array}$ & $\begin{array}{r}24.8 \\
4\end{array}$ & 19.80 & $\begin{array}{l}\text { Verry } \\
\text { Low }\end{array}$ & $\begin{array}{c}\text { Instructi } \\
\text { ve }\end{array}$ \\
\hline 1 & $\begin{array}{c}\text { Panjang } \\
\text { City } \\
\text { Pariam }\end{array}$ & 9.52 & $\begin{array}{r}11.0 \\
6\end{array}$ & $\begin{array}{r}12.1 \\
8\end{array}$ & $\begin{array}{r}15.3 \\
0\end{array}$ & $\begin{array}{r}14.6 \\
7\end{array}$ & 12.55 & $\begin{array}{l}\text { Verry } \\
\text { Low }\end{array}$ & $\begin{array}{c}\text { Instructi } \\
\text { ve }\end{array}$ \\
\hline
\end{tabular}




\begin{tabular}{|c|c|c|c|c|c|c|c|c|c|}
\hline \multirow[t]{2}{*}{$\mathrm{N}$} & \multirow[t]{2}{*}{$\begin{array}{c}\text { Regency/Ci } \\
\text { ty }\end{array}$} & \multicolumn{5}{|c|}{$\begin{array}{c}\text { Ragional Financial Independence } \\
\text { Ratio (\%) }\end{array}$} & \multirow[t]{2}{*}{$\begin{array}{r}\text { Avera } \\
\text { ge }\end{array}$} & \multirow[t]{2}{*}{$\begin{array}{r}\text { Criter } \\
\text { ia }\end{array}$} & \multirow[t]{2}{*}{$\begin{array}{l}\text { elationship } \\
\text { Pattera }\end{array}$} \\
\hline & & $\begin{array}{r}201 \\
2\end{array}$ & $\begin{array}{r}201 \\
3\end{array}$ & $\begin{array}{r}201 \\
4\end{array}$ & $\begin{array}{r}201 \\
5\end{array}$ & $\begin{array}{r}201 \\
6\end{array}$ & & & \\
\hline \multicolumn{10}{|c|}{ an } \\
\hline 1 & $\begin{array}{l}\text { City } \\
\text { Payaku } \\
\text { mbuah }\end{array}$ & 4.41 & 5.20 & 5.07 & 5.50 & 5.01 & 5.04 & $\begin{array}{l}\text { Verry } \\
\text { Low }\end{array}$ & $\begin{array}{l}\text { Instructi } \\
\text { ve }\end{array}$ \\
\hline 1 & $\begin{array}{l}\text { City } \\
\quad \text { Sawahl } \\
\text { unto }\end{array}$ & $\begin{array}{r}11.9 \\
2\end{array}$ & $\begin{array}{r}11.0 \\
9\end{array}$ & $\begin{array}{r}12.2 \\
6\end{array}$ & $\begin{array}{r}16.6 \\
8\end{array}$ & $\begin{array}{r}13.8 \\
8\end{array}$ & 13.17 & $\begin{array}{l}\text { Verry } \\
\text { Low }\end{array}$ & $\begin{array}{l}\text { Instructi } \\
\text { ve }\end{array}$ \\
\hline 1 & City & 9.87 & 7.55 & $\begin{array}{r}11.0 \\
5\end{array}$ & $\begin{array}{r}10.7 \\
7\end{array}$ & 9.97 & 9.84 & $\begin{array}{l}\text { Verry } \\
\text { Low }\end{array}$ & $\begin{array}{l}\text { Instructi } \\
\text { ve }\end{array}$ \\
\hline 1 & Solok City & 6.40 & 5.89 & 6.42 & 7.51 & 7.93 & 6.83 & $\begin{array}{l}\text { Verry } \\
\text { Low }\end{array}$ & $\begin{array}{c}\text { Instructi } \\
\text { ve }\end{array}$ \\
\hline & rage (City) & 9.67 & 9.81 & $\begin{array}{r}11.1 \\
8\end{array}$ & $\begin{array}{r}13.1 \\
1\end{array}$ & $\begin{array}{r}12.6 \\
7\end{array}$ & 11.29 & $\begin{array}{l}\text { Verry } \\
\text { Low }\end{array}$ & $\begin{array}{l}\text { Instructi } \\
\text { ve }\end{array}$ \\
\hline & $\begin{array}{l}\text { rage } \\
\text { (Regency and } \\
\text { City) }\end{array}$ & 7.07 & 7.10 & 9.08 & 9.55 & 9.55 & 3.47 & $\begin{array}{l}\text { Verry } \\
\text { Low }\end{array}$ & $\begin{array}{c}\text { Instructi } \\
\text { ve }\end{array}$ \\
\hline
\end{tabular}

Source: processed data (2018)

Based on Table 3 above, it can be seen that the financial independence of the regencies and cities in the West Sumatra Province for the 2012 to 2016 Period has an average value of $8.43 \%$ and is very low, because it is under the value of $25 \%$. The average regional financial independence ratio of the city government is higher than the average district government financial independence ratio of $11.29 \%$ for the city government and $6.77 \%$ for the district government.

In 2012, the highest regional financial independence ratio for district governments was $8.18 \%$ which was achieved by the regency government of Dharmasraya and the city government which was $14.73 \%$ obtained by the City of Padang. The average regional financial independence ratio in 2012 for the regency government was 5.55\% and the city government was $9.67 \%$ while overall was $7.07 \%$.

For 2013, the highest regional financial independence ratio for the regency government was $7.70 \%$ which was achieved by the Tanah Datar Regency Government. This percentage is lower than the previous year which amounted to $8.18 \%$ achieved by the Regency of Dharmasraya. Whereas for the city government the percentage of regional financial independence ratio increased to $16.19 \%$ which was still obtained by Padang City. The average regional financial independence ratio in 2013 for the district government was 5.37\% and the city government was $9.81 \%$ and overall for the regency and city governments was $7.00 \%$ down $0.07 \%$ from the previous year. 
Furthermore, in 2014, the highest regional financial independence ratio for the regency government was $11.02 \%$ achieved by the Tanah Datar Regency Government. This percentage increased from the previous year of $7.70 \%$ which was also achieved by Tanah Datar Regency. Whereas for the city government the percentage of regional financial independence ratio increased to $19.76 \%$ which was still obtained by Padang City. The average regional financial independence ratio in 2014 for the regency government is $7.75 \%$. This percentage increased from 2012 which had a value of $5.55 \%$ and 2013 of $5.37 \%$. While the average financial independence ratio of the city government is $11.18 \%$. This percentage also increased compared to 2012 which had a value of $9.67 \%$ and in 2013 it was $9.81 \%$. Overall, the percentage of regional financial independence ratio for regency and city governments in 2014 was $9.01 \%$, increasing from the previous year which was $7.00 \%$.

In 2015, the highest regional financial independence ratio for the district government was $10.78 \%$ achieved by the Tanah Datar Regency Government. This percentage decreased from the previous year which amounted to $11.02 \%$ which was also achieved by Tanah Datar Regency. Whereas for the city government the percentage of regional financial independence ratio increased to $23.49 \%$ which was still obtained by the City of Padang. The average regional financial independence ratio in 2015 for the district government was $7.47 \%$. This percentage decreased by $0.28 \%$ compared to the acquisition in 2014 . While the average financial independence ratio of the city government was $13.11 \%$. This percentage increased by $1.93 \%$ compared to 2014 . Overall the percentage of the regional financial independence ratio for regency and city governments in 2015 was $9.55 \%$ increasing by $0.54 \%$ from the previous year.

In 2016, the highest regional financial independence ratio for the district government was $11.12 \%$ achieved by the Tanah Datar Regency Government. This percentage increased by $0.34 \%$ from the previous year which was $10.78 \%$ which was also achieved by Tanah Datar Regency. Whereas for the city government the percentage of regional financial independence increased to $24.84 \%$ ratio which was still obtained by Padang City. The 2016 average regional financial independence ratio for the regency government is $7.70 \%$. This is compared to the acquisition in $0.23 \%$ in 2015 . While the average regional financial independence ratio of the city government was $12.67 \%$. This percentage decreased by $0.23 \%$ compared to 2015 . Overall the percentage of regional financial independence for regency and city governments in 2016 was $9.53 \%$ decreased by $0.02 \%$ from the previous year.

Based on Table 3, we can also see that the average ratio of regency and city financial independence in the Province of West Sumatra, from 2013 to 2015 continued to experience an increase indicating that the increase in local revenue or internal income in the form of local taxes, regional retribution, the results of the management of separated regional assets and other legitimate local revenues are higher than the increase in income other than local original income or external income in the form of transfer funds and other legitimate regional income. Whereas in 2012 to 2013 and 2015 to 2016 the regional financial independence ratio experienced a slight decrease which indicated that the number of increase in external income was higher than the percentage of increase in internal income. One of the external revenues that caused the increase in external income in 2015 to 2016 was the transfer of village funds from the central government to the city and district governments that had villages (or their names equated with villages) as well as increases in other external income such as funds for results $(\mathrm{DBH})$, general allocation funds (DAU), special allocation funds (DAK). For the average financial ratio of the district and city financial independence can be seen in the following figure. 


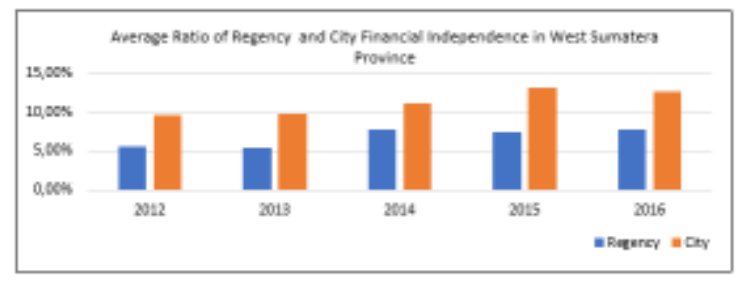

Fig. 2. Average Regional Financial Independence Ratio of Regency and City Governments in West Sumatra Province 2012 to 2016. Source: processed data (2018)

Based on Figure 2 above, we can see that the ratio of regional financial independence of the city government for all years of research is higher than that of the regency government. However, for the movement every year and if we look at 2012 and 2016, the regional financial independence ratio has increased where for the district government in 2012 the regional financial independence ratio was $5.55 \%$ so in 2016 it became $7.70 \%$ meaning that there was an increase of $38.74 \%$. As for the city government in 2012 with a ratio of $9.67 \%$ and in 2016 rose to $12.67 \%$, there was an increase of $31.02 \%$.

By paying attention to Table 2, it is also known that the value of regional financial independence ratios for all regency and city governments in West Sumatra Province is between 0 to $25 \%$ and classified as very low criteria, so that having an impact on the pattern of financial management relations with the central government is instructive. The role of the central government is more dominant than the independence of the regional government or it can be interpreted that the districts and cities in West Sumatra Province are unable to implement regional autonomy viewed from the financial aspect. For this reason, systematic steps are needed, good coordination and maximum effort for the regency and city governments in West Sumatra Province to increase Regional Original Revenue both in terms of local taxes, regional retributions, the results of separated regional wealth management and other income legitimate local area.

\section{Conclusions}

Based on the results of the study it was concluded that the financial independence ratio of regencies and cities in the province of West Sumatra was below 25\% so that it was categorized as very low with an instructive relationship pattern which meant that the role of the central government was still more dominant than the independence of local governments because the regions were unable to implement regional autonomy financially. This is indicated by the small ratio of local revenues compared to central funds transfer revenues, provincial funds transfer revenues and loans.

For this reason, it is hoped that the regional government can optimize the components of local revenue which include local taxes, regional retributions, the results of the separated management of regional wealth and other legitimate local revenue both intensification and non-intensification so that the regional financial independence ratio is greater. If the regional financial independence ratio gets bigger, then the regency and city governments will be more independent to accelerate prosperity through programs and activities that directly touch the needs of the community.

Furthermore, the researcher also suggested to the next researcher to deepen the study of the regional financial independence ratio by examining other objects or connecting with other object studies so that it could contribute to regional financial independence. 


\section{References}

[1] Bastian, I. (2011) Akuntansi Sektor Publik di Indonesia. Yogyakarta: BPFE.

[2] Fahmi (2011) Analisa Laporan Keuangan. Bandung: Alfabeta.

[3] Fitra, H. (2014) 'Analisis Pendapatan Daerah di Era Otonomi Pada Pemerintah Kabupaten Induk dan Kabupaten Pemekaran', Jurnal WRA, 2(1), pp. 369-386. Available at: ejournal.unp.ac.id/index.php/wra/article/download/6150/4774.

[4] Halim, A. (2001) Bunga Rampai : Manajemen Keuangan Daerah. Yogyakarta: UPP AMP YKPN.

[5] Halim, A. (2007) Akuntansi Keuangan Daerah Edisi Revisi. Jakarta: Salemba Empat.

[6] Halim, A. and Theresia (2011) Akuntansi Sektor Publik Akuntansi Keuangan Daerah. Jakarta: Salemba Empat.

[7] Haryani (2016) 'Analisis Kemandirian Dan Efektivitas Keuangan Daerah Kabupaten Bireuen', Jurnal Kebangsaan, 5(9), pp. 50-54.

[8] INDONESIA, U.-U. R. (2004) UNDANG-UNDANG REPUBLIK INDONESIA NOMOR 33 TAHUN 2004.

[9] Mahmudi (2007) Analisis Laporan Keuangan Pemerintah Daerah. Yogyakarta: STIM YKPN.

[10] Presiden Indonesia dan DPRRI (2014) 'UU No. 23 tahun 2014 tentang Pemerintahan Daerah', Pemerintah Republik Indonesia, pp. 1-460. doi: 10.20801/jsrpim.27.3_4_171.

[11] Puspita, R. and Martani, D. (2010) 'Analisis Pengaruh Kinerja dan Karakteristik Pemda Terhadap Tingkat Pengungkapan dan Kualitas Informasi dalam Website Pemda', Seminar Nasional Akuntansi V, 84(1), pp. 1-25. doi: 10.1017/CBO9781107415324.004.

[12] Rahmayati, A. (2016) 'Analisis Kinerja Keuangan Pemerintah Daerah Kabupaten Sukoharjo Tahun Anggaran 2011-2013', Jurnal EKA CIDA, 1(1), pp. 40-54. doi: 10.7454/jvi.v4i2.63.

[13] Ramadhani, F. R. (2016) 'Analisis Kemandirian dan Efektivitas Keuangan Daerah di Kota Tarakan Tahun 2010-2015', Jurnal Ekonomi Pembangunan, 14(01), pp. 85-98.

[14] Risyanto, H. (2015) 'Analisis Kemampuan Keuangan Daerah Dan Kemandirian Keuangan Daerah Serta Pengaruhnya Terhadap Pertumbuhan Ekonomi Kabupaten Garut', Coopetition, 6(1), pp. 21-33.

[15] Tangkilisan, H. . (2007) Manajemen Publik. Jakarta: PT. Grasindo. 